Original Research Article

\title{
Preclinical hematological profile studies of an ayurvedic medicine Siddha Makardhwaja after chronic administration to male sprague- dawley rats
}

\author{
Md. Mamun Sikder*, Proshanta Chakraborty, Md. Ruhul Mahbub, \\ Tasniya Nahiyan Zulfiquar, Md. Nuruzzaman Neon, Nilay Saha, Imtiaj Hossain Chowdhury, \\ M. S. K. Choudhuri
}

Department of Pharmacy, Jahangirnagar University, Savar, Dhaka-1342, Bangladesh

Received: 13 October 2017

Revised: 04 November 2017

Accepted: 07 November 2017

*Correspondence to:

Dr. Md. Mamun Sikder, Email: shikder1753@gmail.com

Copyright: (C) the author(s), publisher and licensee Medip Academy. This is an openaccess article distributed under the terms of the Creative Commons Attribution NonCommercial License, which permits unrestricted noncommercial use, distribution, and reproduction in any medium, provided the original work is properly cited.

\begin{abstract}
Background: Siddha Makardhwaja (SMD) is a classical Ayurvedic formulation markedly used as a traditional medicine in the rural population for various purposes such as stimulant, tonic, and rejuvenator.

Methods: The present study is conducted to evaluate the effect of conventionally prepared SMD on the hematological parameters in experimental animals, for providing scientific data base for its logical use in clinical practice. Acute toxicity tests were conducted to determine the LD50 of the drug. To find out the effect of chronic administration of SMD on hematological parameters it was administered chronically to the male Sprague-Dawley rats at a dose of $40 \mathrm{mg} / \mathrm{kg}$ for 28 days.

Results: In this experiment the TC, DC, various erythrocytic parameters, platelet parameters, ESR were determined. The results of the studies are given below. There is an $(13.41 \%)$ increase in the number of white blood cell count of the male rat, the increase though not significant yet it was prominent $(\mathrm{p}=0.257)$. There is an $(15.87 \%)$ increase in the absolute count of Neutrophils of the male rat, the increase though not significant yet it was prominent $(\mathrm{p}=0.371)$. There is an $(12.29 \%)$ increase in the absolute count of Lymphocytes of the male rat, the increase though not significant yet it was prominent $(\mathrm{p}=0.388)$. There is a statistically significant $(\mathrm{p}=0.035)$ increase in the number of platelet count of the male rat (11.13\% increase). There is a $(2.03 \%)$ decrease in the platelet volume distribution width of the male rat, the decrease though not significant yet it was noticeable $(\mathrm{p}=0.094)$. There is a statistically insignificant $(\mathrm{p}=0.619)(10.0 \%)$ increase in Erythrocyte sedimentation rate in blood from the male rat.

Conclusions: As SMD decreases and increases abnormally on the hematological parameters in body of treated rats, so it should not be administered chronically at a higher dose. Further studies should be done by reducing the administered dose.
\end{abstract}

Keywords: Ayurvedic preparation, Hematological, Rejuvenator, Siddha Makardhwaja

\section{INTRODUCTION}

Ayurvedic medicines have reputation as decent and effective remedies for a number of diseases. ${ }^{1}$ Currently, the World Health Organization (WHO) has officially recognized and recommended large-scale use of herbal (Unani and Ayurvedic) medicines, particularly in the developing countries, as an alternative system of medicine to deliver health care services at the primary health care level. ${ }^{2}$ According to WHO, an estimated 1.5 billion people of the world are now getting treatment with these medicines. ${ }^{3}$ They have a good safety profile also. ${ }^{4}$

Siddha Makardhwaj is an ancient Indian multi-purpose ayurvedic medicine that acts as an alternative, stimulant, 
tonic, and rejuvenator. Its regular use prevents the wrinkles of skin, greying of hair due to old age. Siddha Makardhwaj is also an effective natural aphrodisiac; however, it should be taken only under strict medical supervision. ${ }^{5-9}$

A natural aphrodisiac, this herbal product is known for calming cardiac muscles as well. It contains gold particles or Swarna Bhasma, which is known to have many good benefits for the human body. Ayurveda states that gold, in its element and medicinal formulation can improve intelligence and sharpens memory. ${ }^{5-9}$

Siddha Makardhwaj is included in the Bangladesh National Formulary of Ayurvedic Medicine 1992 (Approved by the Government of Bangladesh vide Ministry of Health and Family Welfare Memo No. Health1/Unani- 2/89/(Part-1) 116 dated 3-6-1991). ${ }^{5}$

\section{METHODS}

\section{Drugs, chemicals and reagents}

For the hematological study, Siddha Makardhwaja (SMD) was collected from Sri Kundeswari Aushadhalaya Limited, Chittagong. Ketamine injection was purchased from ACI Pharmaceuticals Limited, Bangladesh. All other reagents, assay kits and chemicals used in this work were purchased from Human GmbH, Wiesbaden, Germany.

\section{Experimental animals}

Six to eight-week old male Sprague-Dawley rats bred and maintained at the animal house of the Department of Pharmacy, Jahangirnagar University, were used in the hematological experiment. These animals were apparently healthy and weighed $60-70 \mathrm{~g}$. The animals were housed in a well-ventilated clean experimental animal house under constant environmental and adequate nutritional conditions throughout the period of the experiment. They were fed with rat chow prepared according to the formula developed at Bangladesh Council of Scientific and Industrial Research (BCSIR). Water was provided ad libitum and the animals maintained at 12 hours day and 12 hours night cycle. All experiments on rats were carried out in absolute compliance with the ethical guide for care and use of laboratory animals approved by Ethical Review Committee, Faculty of Life Sciences, Department of Pharmacy, Jahangirnagar University.

\section{Experimental design acute pharmacological study}

The acute oral pharmacological test was performed following the guidelines of Organization for Economic Co-operation and Development (OECD) for testing of chemicals with minor modifications (OECD Guideline 425). ${ }^{10}$ Sixteen male mice (30-40g body weight) were divided into four groups of four animals each. Different doses $(50 \mathrm{ml} / \mathrm{Kg}, 60 \mathrm{ml} / \mathrm{Kg}, 70 \mathrm{ml} / \mathrm{Kg}$ and $80 \mathrm{ml} / \mathrm{Kg})$ of experimental drug Siddha Makardhwaja (SMD) were administered by stomach tube. The dose was divided into two fractions and given within 12 hours. Then all the experimental animals were observed for mortality and clinical toxicity signs (general behavior, respiratory pattern, cardiovascular signs, motor activities, reflexes and changes in skin and fur texture) at 1, 2, 3 and 4 hours and thereafter once a day for the next three days following Siddha Makardhwaja (SMD) administration.

\section{Chronic hematological studies}

Prior to the experiment, rats were randomly divided into 2 groups of 8 animals each. One group was treated with SMD in dose $40 \mathrm{mg} / \mathrm{kg}$ and another was used as a control. The control animals were administered with distilled water only as per the same volume as the drug treated group for 28 days. After acclimatization, Ayurvedic medicinal preparation was administered to the rats by intra-gastric syringe between the 10 am to 12 am daily throughout the study period. All experiments on rats were carried out in absolute compliance with the ethical guide for care and use of laboratory animals. The experiment animals were marked carefully on the tail which helped to identify a particular animal. By using identification mark, responses were noted separately for a particular period prior to and after the administration. ${ }^{11}$

\section{Blood samples collection and preparation of serum}

At the end of the 28 days treatment period, after 18 hours fasting, rats from each group were anaesthetized by administration (i.p) of ketamine $(500 \mathrm{mg} / \mathrm{Kg}$ body weight). ${ }^{12}$ Blood samples were collected from post vena cava of rats into EDTA (Ethylene di-amine tetra acetic acid) sample tubes for hematological analysis and into plain sample tubes for serum generation for biochemical analysis. Serum was obtained after allowing blood to coagulate for 30 minutes and centrifuged at $4000 \mathrm{~g}$ for 10 minutesusing bench top centrifuge (MSE Minor, England). The supernatant serum samples were collected using dry Pasteur pipette and stored in the refrigerator for further analysis. All analyses were completed within 12 hours of sample collection. ${ }^{13}$

\section{Determination of hematological profile studies}

Hematological profile studies is involved analysis of parameters such as Red Blood Cells (RBCs) and platelet level determined by Electrical Impedance method. ${ }^{14}$ Hemoglobin (HGB) level determined by modified hemoglobin cyanide method. ${ }^{15}$ The HCT is calculated from the RBC count and the MCV as follows:

$\mathrm{HCT}=(\mathrm{RBC} \times \mathrm{MCV}) / 10$

$\mathrm{MCV}, \mathrm{MCH}$ and MCHC are calculated according to the formula as given by Wintrobe and Diem and Clenter: ${ }^{16,17}$

$\mathrm{MCV}=[\mathrm{HCT}(\%) / \mathrm{RBC}$ count $($ millions $)] \mathrm{X} 10$

$\mathrm{MCH}=[\mathrm{Hb}(\mathrm{g} / \mathrm{dL}) / \mathrm{RBC}$ count (millions) $] \mathrm{X} 10$ 
$\mathrm{MCHC}=[\mathrm{Hb}(\mathrm{g} / \mathrm{dL}) / \mathrm{HCT}(\%)]$ X 100

Mathematically the RDW is calculated with the following formula:

$\mathrm{RDW}=($ Standard deviation of $\mathrm{MCV} \div$ mean $\mathrm{MCV}) \times$ $100 .^{18}$

Two WBC values are provided by the CELL-DYN 3700 System:

1. The WIC (WBC Impedance Count)

2. The WOC (WBC Optical Count).

Impedance resistance was used for the measurement of platelet indices in all blood samples (analyzers CELL DYNN 1700 and GENS) such as platelet count (PLT), mean platelet volume (MPV) and platelet distribution width (PDW). ${ }^{19}$ Erythrocyte Sedimentation Rate (ESR) is measured by Westergren Method. ${ }^{20}$

\section{Statistical analysis}

The data were analyzed using independent sample t-test with the help of SPSS (Statistical Package for Social Science) Statistics 11.5 package (SPSS Inc., Chicago Ill).
All values are expressed as mean \pm SEM (Standard Error Mean) and $\mathrm{p}^{*} \leq 0.05, \mathrm{p}^{* *} \leq 0.01, \mathrm{p}^{* * *} \leq 0.001$ was taken as the level of significant.

\section{RESULTS}

\section{Acute pharmacological study}

The drug (SMD) administered up to a high dose of $80 \mathrm{ml} / \mathrm{Kg}$ produced no mortality of the experimental animals. Thus the LD50 (Median Lethal Dose) value was found to be greater than $80 \mathrm{ml} / \mathrm{Kg}$ body weight. The animals did not manifest any sign of restlessness, respiratory distress, general irritation or convulsion. Since SMD is in the clinical use for rheumatoid arthritis treatment for many years, a limit test was performed in acute oral toxicity study. According to the OECD test guideline 425 when there is information in support of low or non-toxicity and immortality nature of the test material, then the limit test at the highest starting dose level ( $80 \mathrm{ml} / \mathrm{Kg}$ body weight) was conducted. There were no mortality and toxicity signs observed at $80 \mathrm{ml} / \mathrm{Kg}$ body weight. Therefore, it can be concluded that SMD when administered at single dose is non-toxic and can be used safely in oral formulations.

Table 1: Hematological profiles after chronic administration of Siddha Makardhwaja (SMD) in dose 40mg/kg to the male rates.

\begin{tabular}{|lllll|}
\hline Parameters & Control & SMD & p values & \% Change \\
\hline WBC & $4.2875 \pm 0.40683$ & $4.8625 \pm 0.26722$ & 0.257 & $\uparrow 13.41 \%$ \\
\hline Neutro (abs) & $1.3312 \pm 0.16314$ & $1.5425 \pm 0.16020$ & 0.371 & $\uparrow 15.87 \%$ \\
\hline Lympho (abs) & $2.8875 \pm 0.33659$ & $3.2425 \pm 0.21267$ & 0.388 & $\uparrow 12.29 \%$ \\
\hline Mono (abs) & $0.0725 \pm 0.01333$ & $0.0800 \pm 0.01389$ & 0.703 & $\uparrow 10.34 \%$ \\
\hline Neutro (\%) & $31.2500 \pm 3.18338$ & $31.6250 \pm 2.37500$ & 0.926 & $\uparrow 1.2 \%$ \\
\hline Lympho (\%) & $67.1250 \pm 3.25378$ & $66.7500 \pm 2.46221$ & 0.928 & $\downarrow 0.56 \%$ \\
\hline Mono (\%) & $1.6250 \pm 0.26305$ & $1.6250 \pm 0.26305$ & 1.000 & No change \\
\hline RBC & $6.3075 \pm 0.20577$ & $5.9825 \pm 0.19978$ & 0.269 & $\downarrow 5.15 \%$ \\
\hline HGB & $11.0225 \pm 0.38264$ & $10.3550 \pm 0.22421$ & 0.155 & $\downarrow 6.05 \%$ \\
\hline HCT & $33.7750 \pm 1.02378$ & $31.8375 \pm 0.56218$ & 0.119 & $\downarrow 5.74 \%$ \\
\hline MCV & $53.9625 \pm 0.35654$ & $53.0000 \pm 0.51617$ & 0.147 & $\downarrow 1.78 \%$ \\
\hline MCH & $17.4750 \pm 0.16448$ & $17.2250 \pm 0.12211$ & 0.242 & $\downarrow 1.43 \%$ \\
\hline MCHC & $32.3875 \pm 0.19127$ & $32.4875 \pm 0.20740$ & 0.728 & $\uparrow 0.31 \%$ \\
\hline RDW & $12.5625 \pm 0.17107$ & $12.6625 \pm 0.27186$ & 0.760 & $\uparrow 0.80 \%$ \\
\hline PLT & $449.38 \pm 11.89378$ & $499.38 \pm 12.55123$ & $* 0.035$ & $\uparrow 11.13 \%$ \\
\hline MPV & $3.7150 \pm 0.03530$ & $3.7325 \pm 0.04431$ & 0.762 & $\uparrow 0.47 \%$ \\
\hline PDW & $15.7000 \pm 0.15119$ & $15.3875 \pm 0.08543$ & 0.094 & $\downarrow 2.03 \%$ \\
\hline ESR & $1.2500 \pm 0.16366$ & $1.3750 \pm 0.18298$ & 0.619 & $\uparrow 10 \%$ \\
\hline i & & & & \\
\hline
\end{tabular}

$\uparrow:$ increase, $\downarrow$ : decrease; $\mathrm{p}^{*} \leq 0.05, \mathrm{p}^{* *} \leq 0.01, \mathrm{p}^{* * *} \leq 0.001$

\section{Chronic hematological study studies}

Effect of SMD on Hematological profiles of male rats: There is an $(13.41 \%)$ increase in the number of white blood cell count of the male rat, the increase though not significant yet it was prominent $(\mathrm{p}=0.257)$. There is an $(15.87 \%)$ increase in the absolute count of Neutrophils of the male rat, the increase though not significant yet it was 
prominent $(\mathrm{p}=0.371)$. There is an $(12.29 \%)$ increase in the absolute count of Lymphocytes of the male rat, the increase though not significant yet it was prominent $(p=0.388)$. There is a statistically insignificant $(p=0.703)$ $(10.34 \%)$ increase in the absolute count of Monocytes of the male rat. There is a negligible $(1.20 \%)$ increase in the percentage of Neutrophil count of the male rat, which was statistically not at all significant $(\mathrm{p}=0.926)$. There is a negligible $(0.56 \%)$ decrease in the percentage of Lymphocyte count of the male rat, which was statistically not at all significant $(p=0.928)$. There was no change noticed in the percentage of Monocyte count of the male rat. There is a $(5.15 \%)$ decrease in the total numbers in the red blood cells of the male rat, the decrease though not significant yet it was prominent $(\mathrm{p}=0.269)$. There is a $(6.06 \%)$ decrease in the Hemoglobin content of the blood of the male rat, the decrease though not significant yet it was prominent $(\mathrm{p}=0.155)$. There is a $(5.74 \%)$ decrease in the Hematocrit level of the blood of the male rat, the decrease though not significant yet it was prominent $(p=0.119)$. There is a $(1.78 \%)$ decrease in the Mean corpuscular volume, a red cell index of the male rat, the decrease though not significant yet it was prominent $(\mathrm{p}=0.147)$.

There is a $(1.43 \%)$ decrease in the Mean corpuscular hemoglobin, a red cell index of the male rat, the decrease though not significant yet it was prominent $(p=0.242)$. There is a negligible $(0.31 \%)$ increase in the Mean corpuscular hemoglobin concentration, a red cell index of the male rat, which was statistically not at all significant $(p=0.728)$. There is a negligible $(0.8 \%)$ increase in the red cell volume distribution width, a red cell index of the male rat, which was statistically not at all significant $(\mathrm{p}=0.760)$. There is a statistically significant $(\mathrm{p}=0.035)$ increase in the number of platelet count of the male rat ( $11.13 \%$ increase). There is a negligible $(0.47 \%)$ increase in the mean platelet volume of the male rat, which was statistically not at all significant $(\mathrm{p}=0.762)$.

There is a $(2.03 \%)$ decrease in the platelet volume distribution width of the male rat, the decrease though not significant yet it was noticeable $(\mathrm{p}=0.094)$. There is a statistically insignificant $(\mathrm{p}=0.619)(10.0 \%)$ increase in Erythrocyte sedimentation rate in blood from the male rat. There was no change noticed in the male rat cutaneous tail bleeding time. There is a statistically insignificant $(\mathrm{p}=0.510)(1.62 \%)$ shortening of whole blood clotting time in male rats.

\section{DISCUSSION}

Hematology is the branch of medicine concerned with the study of the cause, diagnosis, treatment, and prevention of diseases related to blood. It involves treating diseases that affect the production of blood and its components, such as blood cells, hemoglobin, blood proteins, bone marrow, platelets, blood vessels, spleen, and the mechanism of coagulation. Such diseases might include hemophilia, blood clots, other bleeding disorders and blood cancers such as leukemia, multiple myeloma, and lymphoma. The laboratory work that goes into the study of blood is frequently performed by a medical technologist or medical laboratory scientist. Many hematologists work as hematologist-oncologists, also providing medical treatment for all types of cancer.

Blood is a tissue which is very vulnerable to a wide range of toxic insults and the effects may be far reaching and grave. To a large extent, toxicity to the bone marrow can be assessed by peripheral blood measurements. Marked hematological changes at all dose levels would indicate that a drug would not be a suitable candidate for development. However, the sensitivity of hematological measurements is increasing constantly with the development of micro-automated methods. As a result, it should be recognized that subtle but significant treatmentrelated changes may come to light which have little clinical relevance. The analysis of blood parameters is closely related to risk evaluation because when tests involve rodents, the hematological system has a higher predictive value of any abnormal toxicity signs and symbols in humans. ${ }^{21} \mathrm{We}$ found noticeable hemolytic changes on some major hematological parameters.

White blood cells (WBCs) are the cells of the immune system that are involved in protecting the body against both infectious disease and foreign invaders which increased highly to the treated rats but it was not significant at all. Platelets, also called thrombocytes are a component of blood whose function (along with the coagulation factors) is to stop bleeding by clumping and clotting blood vessel injuries. The main function of platelets is to contribute to hemostasis: the process of stopping bleeding at the site of interrupted endothelium. ${ }^{22}$ In this study we found, Platelets increased to the SMD treated rats. Thrombocytosis (or thrombocythemia) is the presence of high platelet counts in the blood. ${ }^{23}$ Although often symptomless it can predispose to thrombosis in some patients. Thrombocytosis can be contrasted with thrombocytopenia, a loss of platelets in the blood.

\section{ACKNOWLEDGEMENTS}

The authors are thankful to Focused Research on Ayurvedic Medicine and Education (F.R.A.M.E) Laboratory, Department of Pharmacy and all faculty members and the technical staffs of the Department of Pharmacy, Jahangirnagar University for their kind cooperation. We would express our special thanks to $\mathrm{Mr}$. Shafiqul Islam for ensuring a constant supply of animals followed by proper maintenance and care of these animals during all throughout the experimental period.

\author{
Funding: No funding sources \\ Conflict of interest: None declared \\ Ethical approval: The study was approved by the Ethical \\ Review Committee, Faculty of Life Sciences, Department \\ of Pharmacy, Jahangirnagar University
}




\section{REFERENCES}

1. WHO. Regional Office for the Western Pacific Seminar on the Use of Medicinal Plants in Health Care, Final Report, Tokyo, Japan; 1977:13-17.

2. WHO. WHO Launches the First Global Strategy on Traditional and Alternative Medicine, Press Release, WHO/ 38; 2002.

3. WHO. Consultation Meeting on Traditional Medicine and Modern Medicine: Harmonizing the Two Approaches. Geneva, World Health Organization, (document reference (WP) TM/ICP/TM/001/RB/98RS/99/GE/32(CHN), Geneva, Switzerland: 1999a.

4. Ernst E. Ayurvedic medicines. Pharmacoepidemiol Drug Saf. 2002;11(6):455-6.

5. Anonymous, (2011b) Bangladesh National Formulary of Ayurvedic Medicine; 1992. (Approved by the Government of Bangladesh vide Ministry of Health and Family Welfare Memo No. Health-1/Unani2/89/(Part-1) 116 dated 3-6-1991). National Unani and Ayurvedic Formulary Committee Bangladesh Board of Unani and Ayurvedic Systems of Medicine, 38, Bangabandhu Avenue, Dhaka-1000. $2^{\text {nd }} \mathrm{Ed} ; 2011$.

6. Anonymous, (1978a) Ayurvedic Formulary of India, The Government of India, Ministry of Health and Family Welfare, Department of Health, New Delhi. Volume I, Part I, $1^{\text {st }}$ Edition; 1978;1(1):324. (2 $2^{\text {nd }}$ ed., part I:488).

7. Anonymous, (1978b) Hand book of Ayurvedic and herbal medicines with formulae: with directory of manufacturers and suppliers of plants, equipment and machineries, packaging materials and raw materials suppliers. Engineers India Research Institute, Delhi, 1978;XVIII:382.

8. OECD Guideline (425) for the testing of chemicals, Guidance document on acute oral toxicity, Environmental Health and Safety Monograph Series on Testing and Assessment; 2008:1-27.

9. Stevens KR, Gallo MA. Practical consideration in the conduct of chronic toxicity studies, Principles and Methods of Toxicology, $2^{\text {nd }}$ Edn. Chap. 7: 1989.

10. OECD Guideline (425) for the testing of chemicals, Guidance document on acute oral toxicity, Environmental Health and Safety Monograph Series on Testing and Assessment; 2008:1-27.

11. Stevens KR, Gallo MA. Practical consideration in the conduct of chronic toxicity studies, Principles and Methods of Toxicology, $2^{\text {nd }}$ Edn. Chap. VIII: 1989.

12. Ringler H, Dabich L. Hematology and clinical biochemistry. In: The Laboratory Rat Biology and
Disease [Baker HL ed]. American College of Laboratory Animal Medicine Series Academic Press: 1979.

13. Wolford ST, Schoer RA, Gohs FX, Gallo PP. Reference range database for serum chemistry and haematology values in laboratory animals. J Tox Environ Hlth, 1986;18:161-88.

14. Tatsumi N, Tsuda I, Furota A, Takubo T, Hayashi M, Matsumoto H. Principle of Blood Cell CounterDevelopment of Electric Impedance Method. Sysmex J Int. 1999;9:8-20.

15. van Kampen EJ, Zijlstra WG. Standardization of hemoglobinometry II. The hemiglobincyanide method. Clinica Chimica Acta. 1961;6(4):538-44.

16. Wintrobe MM. Clinical Hematology, $6^{\text {th }}$ ed. Lea and Febiger, Philadelphia, USA: 1967.

17. Diem KL. Clenter. Scientific Tables, $7^{\text {th }}$ Ed. Geigy Pharmaceuticals, Basel, Switzerland; 1970.

18. Encyclopedia of Surgery: A Guide for Patients and Caregivers Red blood cell indices Retrieved on 5 April 2009.

19. Girling JH. An automatic platelet counting technique. The Journal of medical laboratory technology. 1962;19:168-73.

20. Westergren A. Diagnostic tests: the erythrocyte sedimentation rate range and limitations of the technique. Triangle. 1957;3(1):20-5.

21. Olson H, Betton G, Robinson D, Thomas K, Monro A. Concordance of toxicity of pharmaceuticals in humans and in animals. Regulatory Toxicology and Pharmacology. 2000;32:56-67.

22. Laki K. Our ancient heritage in blood clotting and some of its consequences. Annals of the New York Academy of Sciences. 1972;202:297-307.

23. Harrison CN, Bareford D, Butt N, Campbell P, Conneally E, Drummond $\mathrm{M}$, et al. Guideline for investigation and management of adults and children presenting with a thrombocytosis. British journal of haematology. 2010 May 1;149(3):352-75.

Cite this article as: Sikder MM, Chakraborty $\mathrm{P}$, Mahbub MR, Zulfiquar TN, Neon MN, Saha N, et al. Preclinical hematological profile studies of an ayurvedic medicine "Siddha Makardhwaja" after chronic administration to male sprague-dawley rats. Int J Basic Clin Pharmacol 2018;7:93-7. 